\title{
INTERNATIONAL TELECOMMUNICATIONS: DYNAMICS OF REGULATION OF A RAPIDLY EXPANDING SERVICE
}

\author{
Asher H. ENDE*
}

I

\section{A Profile of the Regulatory Mrssion}

The Communications Act of 1934 , as amended ${ }^{1}$ (the Communications Act), and the Communicatons Satellite Act of $1962^{2}$ (the Satellite Act) provide for pervasive and all-encompassing federal regulation of international telecommunications. The basic purposes to be achieved by such regulation are declared to be "to make available, so far as possible, to all the people of the United States a rapid, efficient, Nation-wide, and world-wide wire and radio communications service with adequate facilities at reasonable charges, ....."

This broad and general statement of purposes is supplemented by the Declaration of Policy and Purposes in the Satellite Act. In that act, Congress declared it to be the policy of the United States to establish, in conjunction and cooperation with other countries and as expeditiously as practicable, a commercial communications satellite system which, as part of an improved global communications network, would be responsive to public needs and national objectives, would serve the communications needs of this country and other countries, and would contribute to world peace and understanding. ${ }^{3}$ In effectuating the above program, care and attention are to be directed toward providing services to economically less developed countries and areas as well as more highly developed ones, toward efficient and economical use of the frequency spectrum, and toward reflecting the benefits of the new technology in both the quality of the services provided and the charges for such services. ${ }^{4}$ United States participation in the global system is to be in the form of a private corporation subject to appropriate governmental regulation. ${ }^{5}$ All authorized users are to have nondiscriminatory access to the satellite system. Competition is to be strengthened, and the antitrust laws are to be applicable to the corporation created by the Satellite Act and to persons and companies participating in its ownership. ${ }^{6}$

* Deputy Chief, Common Carrier Bureau, Federal Communications Commission.

The opinions expressed in this article, except when supported by specific citation to a Commission decision or other official pronouncement, are those of the author and do not necessarily reflect the views or policies of the Federal Communications Commission. This article was prepared in the early fall of 1969 and thus may not include all occurrences to date in this rapidly changing industry.

${ }^{1} 47$ U.S.C. $\$$ I5I et seq. $\left(\mathrm{x} 66_{4}\right)$.

${ }^{2} 47$ U.S.C. $\$$ 7oI et seq. (1964).

${ }^{3}$ Id. $\$$ 7or (a).

II. $\$ 70 \mathrm{Or}(\mathrm{b})$.

Id. $\$ 70 \mathrm{O}(\mathrm{c})$.

${ }^{\circ}$ Id. 
In general, the provisions of the Communications Act are to be applicable to the furnishing of satellite services, except where the two acts are inconsistent, in which case the Satellite Act is to govern. ${ }^{7}$ The corporation created pursuant to the Satellite Act, the Communications Satellite Corporation (Comsat), is to be deemed a common carrier within the meaning of the appropriate provisions of the Communications Act and is to be fully subject to the provisions of title II and title III of the Communications Act. Furthermore, the provision of earth station facilities by one communication carrier to one or more other such carriers is to be deemed a common carrier activity fully subject to the Communications Act. ${ }^{8}$

The Communications Act is applicable to all interstate and foreign communications by wire and radio, to all interstate and foreign transmission of energy by radio, which originates and/or is received within the United States, and to all persons engaged within the United States in such communication or such transmission of energy by radio." Foreign communication is defined as "communication . . . from or to any place in the United States to or from a foreign country."10

It is clear from the foregoing that the jurisdiction of the federal government-and particularly of the Federal Communications Commission (Commission), which was created by the Communications Act and given supplemental powers in the Satellite Act-over foreign or international communications is very broad indeed. The aforementioned general grants of power are amplified and supplemented by specific provisions in both the Communications Act and the Satellite Act which spell out the nature and extent of the Commission's jurisdiction over the facilities, services, charges, practices, regulations, records, and acts of communications common carriers.

Specifically, under the Communications Act, it is the duty of every common carrier engaged in interstate or foreign communication to furnish communications service upon reasonable request. ${ }^{11}$ The Commission, after opportunity for hearing, can order the establishment of physical connections with other carriers, the establishment of through routes and charges, the division of such charges, and the establishment and provision of facilities and regulations for the operation of through routes. ${ }^{12}$ All charges, practices, classifications, and regulations for and in connection with communication service are to be just and reasonable, and, if unjust and unreasonable, are declared unlawful. ${ }^{13}$ Unjust and unreasonable discriminations and preferences are declared to be unlawful. ${ }^{14}$ All common carriers of foreign communications are required to file, and keep open for public inspection, schedules setting forth their

${ }^{7}$ Id. $\$ 74 \mathrm{I}$.

${ }^{8}$ Id.

${ }^{\circ}$ Communications Act of 1934,47 U.S.C. $\$ I_{52}$ (a) (x964).

${ }^{10} \mathrm{Id}$. $\$ 53(\mathrm{f})$.

${ }^{11} I d$. $\$ 201(\mathrm{a})$.

${ }^{12} \mathrm{Id}$.

${ }^{18}$ Id. $\S 20 \mathrm{I}(\mathrm{b})$.

${ }^{14} \mathrm{Id}$. 
own charges and those of their connecting carriers. ${ }^{15}$ No changes may be made in such schedules except on the filing of proposed new tariff schedules giving due notice to the Commission and the public. ${ }^{16}$ Furthermore, no carrier may charge, demand, collect or receive a different compensation for any communication or service in connection therewith than is specified in the schedule then in effect. Refunds and rebates, as well as the extension of privileges not specified in effective tariff schedules, are prohibited. ${ }^{17}$ The Commission is given the right to suspend schedules setting forth new rates or changes in existing rates either on complaint or on its own motion. ${ }^{18}$ After hearing, the Commission may fix just and reasonable charges, and may prohibit carriers from demanding or collecting charges other than those prescribed. ${ }^{10}$ Jurisdiction is given to the Commission to entertain complaints and suits for recovery of damages with respect to the failure of carriers to comply with the Communications Act. ${ }^{20}$ The Commission is also given plenary powers with respect to the valuation of carrier property, and is required to keep itself informed on all new construction, extensions, improvements, retirements, and other changes in the property of common carriers. ${ }^{21}$ The Commission is authorized to require annual and other reports; ${ }^{22}$ to prescribe forms for the keeping of accounts, records, and memoranda; ${ }^{23}$ and to prescribe depreciation charges. ${ }^{24}$ The Commission is also empowered to make inquiries into the management of the business of all carriers subject to the act and to keep itself informed as to the manner and method in which such business is conducted, as well as about technical developments and improvements in wire and radio communication, all to the end that the benefits of new inventions and developments may be made available to the people of the United States. ${ }^{25}$ The Commission is further empowered to examine the transactions of common carriers relating to the furnishing of equipment, supplies, research, and services which may affect the charges made, or the services rendered, to the public. ${ }^{26}$

No carrier may use or operate any apparatus for the transmission of communications or signals, by radio, except in accordance with a license granted by the Commission on a finding of public interest, convenience, and necessity. ${ }^{27}$ Carriers may not undertake the construction of any new line or an extension thereof, or acquire or operate any line or extension thereof, or engage in transmission by means of any

\footnotetext{
${ }^{10}$ Id. $\$ 203(\mathrm{a})$.

${ }^{10} \mathrm{Id} . \S 203(\mathrm{~b})$.

${ }^{17} \mathrm{Id} . \S 203(\mathrm{c})$.

${ }^{18}$ Id. $\$ 204$.

${ }^{10} \mathrm{Id}$. $205(\mathrm{a})$.

${ }^{20} I d$. $\S \S 206-09$.

${ }^{21}$ Id. 213 .

${ }^{23}$ Id. \$ 219.

${ }^{33} \mathrm{Id}$. $\$ 220$.

${ }^{34}$ Id. $\$ 220(\mathrm{~b})$.

${ }^{20}$ Id. \$2I8.

${ }^{20} I d . \$ 215$.

${ }^{27}$ Id. \$ $30 \mathrm{r}$.
} 
such additional or extended line unless there shall have been first obtained from the Commission a certificate that the present or future public convenience and necessity require the construction or operation, or construction and operation, of such an additional or extended line; and carriers may not reduce, impair, or discontinue service to a community or part thereof, unless they have first obtained from the Commission a certificate that neither the present nor future public convenience and necessity will be adversely affected thereby. ${ }^{28}$

In the Satellite Act the Commission was given additional regulatory powers and responsibilities with respect to satellite communications. Specifically, these included the power or obligation: ${ }^{2 \theta}$

(a) to insure effective competition, including the use of competitive bidding, in the procurement of the apparatus, equipment, and services required for the establishment and operation of the satellite system and the ground stations;

(b) to insure that authorized carriers shall have nondiscriminatory use of, and equitable access to, both the space segment and the earth stations under just and reasonable charges;

(c) to regulate the manner in which available facilities of the space segment and earth stations are allocated among the users thereof;

(d) to require, upon request of the Secretary of State and after hearing, the establishment of communication facilities with particular foreign points;

(e) to insure that the facilities of the system are technically compatible and interconnected operationally not only with each other but with existing communication facilities;

(f) to insure that any economies made possible by the satellite system are appropriately reflected in rates for public communications services;

(g) to approve the technical characteristics of both the space segment and the earth stations;

(h) to grant authorizations for earth stations to Comsat, to one or more authorized carriers, or to Comsat and one or more authorized carriers without preference to any of the foregoing;

(i) to authorize the issuance of instruments of indebtedness or capital stock by Comsat, other than the initial issue of capital stock;

(j) to insure that no substantial additions are made by either Comsat or the carriers to facilities of the satellite system unless required by the public interest, convenience, and necessity.

In regulating the facilities and services of international communications carriers, the Commission must face many unique factors:

(x) There exists at present, and has always existed, active competition between

${ }^{28} I d . \$ \$ 2 \times 4($ a) $-(\mathrm{c})$.

${ }^{29}$ Communications Satellite Act of 1962,47 U.S.C. $\$ 721(c)$ (r964). 
the various telegraph carriers providing international facilities and services. At present the competing telegraph carriers are ITT World Communications Inc. and Press Wireless, Inc., indirect subsidiaries of International Telephone and Telegraph Corporation; RCA Global Communications, Inc. (formerly RCA Communications, Inc.), a subsidiary of the RCA Corporation; Western Union International, Inc., controlled by American Securities Corporation; as well as four minor carriers-Tropical Radio Telegraph Company, a subsidiary of United Fruit Company, control of which was recently acquired by AMK Corporation; United States-Liberia Radio Corporation, a subsidiary of Firestone Tire \& Rubber Company; Cable and Wireless/Western Union International, Inc., owned fifty per cent by Western Union International, Inc., and fifty per cent by Cable and Wireless (West Indies), Ltd.; and The French Cable Company.

(2) Existing law prohibits the merger of these international telegraph carriers, when such a merger would substantially lessen competition or create monopoly. ${ }^{30}$

(3) International telephone service for the contiguous forty-eight states is provided primarily by American Telephone and Telegraph Company; the Hawaiian Telephone Company, a subsidiary of General Telephone and Electronics Corporation, provides such service in Hawaii; All America Cables and Radio, Inc. (formerly ITT Cable and Radio, Inc.-Puerto Rico) and ITT Communications, Inc-Virgin Islands, indirect subsidiaries of International Telephone and Telegraph Corporation (ITT), provide such service in Puerto Rico and the Virgin Islands, respectively; RCA Global Communications, Inc., provides such service in Guam; and the Alaskan Communications System, a unit of the United States Air Force provides such service in Alaska. The latter organization is not regulated by the Commission.

(4) The creation of Comsat introduced another element into the international communications field. That company has a monopoly in the provision of the space segment for international communication service via satellite. This fact made it necessary to establish appropriate rules, regulations, and practices with respect to the nature of the services and facilities provided by Comsat and the relationship of such services and facilities to those provided by the international telegraph carriers and telephone companies.

(5) Technological developments both in terrestrial facilities and in satellite facilities have made it clear that in both fields there were outstanding opportunities to realize economies of scale. Therefore, considerations of efficiency and economy, as well as the monopoly in international satellite communications given to Comsat, favor reliance upon multilpurpose, high-

${ }^{30}$ Communications Act of 1934,47 U.S.C. $\$ \S 313-14$. See also 15 U.S.C. $\$ 2$ (a) (I964). 
capacity facilities to provide the international link for handling the traffic of the various competing companies in lieu of individual facilities, owned and operated separately by each of the carriers providing international services.

During the past twenty years the Commission, therefore, has been faced with a series of evolving problems relating to the nature and extent of the competition to be permitted among international telegraph carriers; the nature and extent of the competition between telephone companies and international telegraph carriers and the rationalization thereof; the relationship between Comsat and both telephone and telegraph carriers in the provision of service directly to users; the ownership and operation of satellite earth stations; and the authorization of terrestrial or satellite facilities to meet growing demands for service. In addition, the Commission has been concerned with the evolution of appropriate rate structures, patterns, and levels to assure the public that the charges it is paying for services are just and reasonable and further to insure, as required by the Satellite Act, that economies made possible by this new technology are, in fact, reflected appropriately in the rates charged to the public. All of the foregoing problems are immensely complicated by the fact that every international circuit terminates in a foreign country which has sovereign rights and controls its end of each international circuit. The regulation of international communications, therefore, necessarily involves a high degree of accommodation with each of the foreign entities with whom communication activities are conducted.

Finally, and aside from all of the foregoing, the Commission, throughout its existence, has also been concerned with the basic question of whether and how the international communications industry could or should be restructured to operate most effectively and efficiently. Originally, this concern focused on whether appropriate legislation should be enacted to permit the merger of the competing international telegraph carriers. More recently, with the development of high-capacity facilities and the creation of Comsat, the area of concern has widened to encompass the question of whether the entire industry engaged in providing international communications facilities should be merged. Thus, at present, the major outstanding question is not only whether there should be a merger of the various international telegraph carriers but also whether the merger should encompass the international facilities of the telephone companies as well as Comsat.

\section{II}

\section{Development of the Industry and Regulatory Policy}

\section{A. The Emergence of a Cautiously Procompetitive Policy for Telegraph Carriers}

Policy problems relating to competition among telegraph carriers first arose when Mackay Radio and Telegraph Company, Inc., a predecessor corporation of ITT 
World Communications Inc., sought authority to compete directly with RCA Global Communications, Inc., in providing radiotelegraph service between the United States and Oslo, Norway. ${ }^{31}$ The Commission, at that time, refused to grant the application for competing circuits, holding in essence that where adequate service is being provided, a competing circuit would not be authorized. The Commission's decision was sustained on appeal. ${ }^{32}$

This policy of restricting competition was generally followed until World War II, when the Board of War Communications requested the authorizations of parallel and forked circuits as a means of protecting essential communications. ${ }^{33}$

Immediately after World War II, the United States entered into an agreement ${ }^{34}$ with countries of the British Commonwealth for the retention of only one direct radiotelegraph circuit with Australia, New Zealand, and India, where duplicating circuits had been established during the war, and for the opening of single direct radiotelegraph circuits to some eight other commonwealth points. Confronted with competing applications for these points, but limited by the agreement to granting only one circuit to each, the Commission determined that it could best maintain competition by allocating circuits among the competing carriers, each of which it found qualified, in such fashion as to give them the opportunity to obtain proportionately as much traffic from these points as they then enjoyed on a world-wide basis. $^{35}$

In r946, Mackay Radio and Telegraph Company, Inc., determined to seek review of the single circuit policy and applied for authority to duplicate existing radiotelegraph circuits of RCA Global Communications, Inc., to the Netherlands, Portugal, and Surinam. After hearing, the Commission reversed its single circuit policy and made a grant of duplicating competitive circuits to the Netherlands and Portugal, where the volume of traffic indicated that competition was reasonably feasible, even though service already provided was adequate and no new services or lower rates were offered by the competing applicant. ${ }^{36}$ It denied the application for Surinam on the grounds that there was not sufficient traffic to support a duplicate circuit to that point. The Commission based its decision on the premise that there was a national policy in favor of competition. On appeal, the Commission's decision was reversed in the circuit court, ${ }^{37}$ essentially on the ground that, where no specific

\footnotetext{
${ }^{81}$ Mackay Radio \& Tel. Co., 2 F.C.C. 592 (1936).

${ }^{82}$ Mackay Radio \& Tel. Co. v. FCC, 97 F.2d 64I (D.C. Cir. I938).

${ }^{33}$ Authorizations granted during this period were initially by special temporary authority, but to the extent that new points became active by April 1943, they were included in regular licenses. During the period May I940 to April I943, RCA Global Communications, Inc., was authorized to communicate with 39 additional points of which I8 became active; Mackay Radio and Telegraph Company, Inc., was authorized to communicate with 56 additional points of which 15 became active, and Press Wireless, Inc., was authorized to communicate with 20 points, of which six became active.

${ }^{84}$ Telecommunications Agreement with United Kingdom, Dec. 4, I945, 60 Stat. I644 (I946).

${ }^{80}$ Mackay Radio \& Tel. Co., I2 F.C.C. 526 (1947).

${ }^{80}$ Mackay Radio \& Tel. Co., I5 F.C.C. 690 (r95r).

${ }^{87}$ RCA Communications, Inc. v. FCC, 201 F.2d 694 (D.C. Cir. I952).
} 
tangible public benefits were shown, the required public interest could not be made to justify a duplicating circuit. On further appeal to the Supreme Court, the circuit court was reversed, and the matter was remanded to the Commission. ${ }^{38}$ In essence, the Supreme Court held that, in a field which is so regulated as this one, the Commission could not rely on national policy in favor of competition and assume that competition is bound to be of advantage. On the other hand, the Court found that the Commission could rely on competition as an aid or adjunct of regulation and as a relevant factor in weighing the public interest, provided it could also make the finding, supported by evidence of record, that competition would serve some beneficial purpose such as maintaining or improving service. In making this finding, the Commission was not required to find that the applicant demonstrated tangible benefits but only that there was ground for reasonable expectation of some beneficial effect.

On remand, the Commission held further hearings and made the findings which met the standards set by the Supreme Court by tracing the beneficial effects that competition had had on the services provided and rates charged by competing carriers. It concluded that there was good ground for finding that competition would, in fact, serve a beneficial purpose and reaffirmed its grant of the circuits to the Netherlands and Portugal. ${ }^{39}$ Upon appeal, the Commission's decision was upheld. ${ }^{40}$

Since then the Commission has followed the basic standards set forth by the Supreme Court in the above-cited decision and has permitted direct competition between international telegraph carriers in those instances where competition was reasonably feasible and some benefit therefrom could reasonably be expected. In pursuance of this policy, duplicate direct circuits were established between the United States and most major countries in the world which were willing to establish facilities at their ends of the circuits. ${ }^{41}$

\section{B. International Telephony}

International telephone service was first established by radio in the late I920s between the United States and Great Britain. In the ensuing years, service, provided primarily by radio facilities, was extended to most countries of the world. In many instances the service was less than satisfactory because of the relatively erratic quality available in those days over radiotelephone circuits. For this reason and because of the high basic rate (e.g., U.S.-United Kingdom, $\$ 75$ per three minutes in 1927, which declined to $\$ 12$ by 1946 , and the latter has remained the basic rate for a personto-person call), radiotelephony remained a relatively luxury, and there was comparatively little intermodal competition with the telegraph services.

After World War II, with the growth of international trade and the increase in international travel, commercial requirements for international telecommunications

\footnotetext{
${ }^{38}$ FCC v. RCA Communications, Inc., 346 U.S. 86 (1953).

${ }^{30}$ Mackay Radio \& Tel. Co., I9 F.C.C. I32I (I955).

${ }^{40}$ RCA Communications, Inc. v. FCC, 238 F.2d 24 (D.C. Cir. I956).

11 See, e.g., Mackay Radio \& Tel. Co., 28 F.C.C. 23 I (1960), involving a circuit to Switzerland.
} 
facilities increased. At the same time, U.S. commitments to our allies and general global obligations increased the requirements of the government for communication facilities to various parts of the world. Demands also increased not only for conventional message service, both voice and nonvoice, but also for leased circuit facilities. Leased circuit facilities are those wherein a direct connection between the two points is made available to the customer on a full-time basis. Because of the high cost and relative unreliability of radio facilities for telephone or voice use, leased circuits were acquired primarily for telegraph use. The development of errordetecting equipment and automatic correction equipment made it possible and feasible to provide such services, as well as international teleprinter services (telex), between the United States and many foreign countries.

In the interim, aware of the growing demands ${ }^{42}$ and the need for high-quality services, $A T \& T$ in the United States and other entities in certain other countries abroad were developing advanced and sophisticated equipment-particularly repeaters, which restore the strength and quality of a signal. Repeaters of great reliability and long life when placed in a cable at the bottom of the ocean would make possible the use of cables to carry the human voice across the oceans. After many years of experimentation, AT\&T and the British Post Office determined in the early I950s that they had developed repeaters of adequate capacity and reliability and sufficiently long life to lay a cable across the Atlantic Ocean which would provide high-quality telephone service between these respective countries. The original cable, which ran between Scotland and Nova Scotia with microwave connections to the United States, was completed in 1956 . The cable, which could handle thirty-six telephone conversations simultaneously, was an instant success. Telephone traffic volume between the United States and Great Britain almost doubled in the year after it was installed. As a result of this success, a series of additional telephone-grade cables were laid to many points. The U.S. mainland was connected by cable with Alaska in 1956 and with Hawaii in 1957. A second transatlantic cable to France was opened in 1959. The U.S. mainland was connected with Puerto Rico by cable in I960. A third transatlantic cable to Great Britain was opened in 1963. The mainlandHawaii cable was extended to Japan, via Midway, Wake, and Guam, by a cable opened in 1964 , and a further section between Guam and the Philippines was also opened in 1964 . A second mainland-Hawaii cable (in part to provide capacity for service between the mainland and Japan and the Philippines) was also opened in I964.

The British Commonwealth was also active in providing telephone-grade cables beginning with a cable between Great Britain and Canada devoted primarily to commonwealth traffic in Ig6r. This was followed by a transpacific cable from Vancouver to Australia via Hawaii and New Zealand, opened for service in 1963 , and

\footnotetext{
${ }^{49}$ In 1948 , the number of overseas telephone calls was $7 \times 5,455$; in $1954,1,351,7 \times 5$. In the same years telegraph messages increased from $18,602,000$ to $21,330,000$; overseas telex service, which was inaugurated in 1950 , increased from 16,077 minutes in that year to 504,000 minutes in 1954 .
} 
finally a cable which ran from Australia through Guam to Hong Kong and Singapore, opened for service during the period rg65-1967.

Rapid improvements were made in the design and capacity of the cables. The original translatlantic cables had been capable of handling only thirty-six simultaneous conversations. Furthermore, the repeaters were unidirectional, so that two separate cables had to be laid to carry a two-way conversation. In the second generation of cables put into service in the early 1960 , repeaters capable of handling a conversation in both directions on a single cable were developed. These cables also had the capacity to handle I28 rather than thirty-six simultaneous conversations. In order to meet ever-growing demand, techniques were developed to increase the number of circuits form thirty-six to forty-eight in the first generation and from 128 to $13^{8}$ in the second generation. In addition, by taking advantage of the pauses in speech, by a device called TASI (Time Assignment Speech Interpolation) the cables' capacity to handle telephone conversations in the future increased considerably.

\section{Intermodal Competition}

This vast development of telephone use, together with the availability of such cables to provide leased circuit services, had a heavy impact on the business and revenues of the telegraph carriers. ${ }^{43}$ Originally, the cables were laid by AT\& $\&$ in connection with its overseas telephone correspondents for telephone use. However, the cables were easily capable of handling telegraph traffic of all types because a given unit of such traffic requires considerably less capacity than a given unit of telephone traffic. AT\&T originally made cable facilities available to the telegraph carriers under the same terms and conditions as it would lease them to the general using public. Thus, the telegraph carriers were totally unable to compete with AT\&T in the provision of leased voice-grade circuits for leased voice/record use because the cost to them of such a circuit in the telephone cables was identical with the charge they would have to make to potential customers for leased circuits to enable them to compete with AT\&T for such traffic. In order to enable the telegraph carriers to maintain their ability to provide the necessary telegraph-grade services, it became clear that some remedial action would have to be taken.

The matter came to a climax in 1964 when AT\& $\mathrm{T}$ applied for authority to install an additional transatlantic cable (TAT-4), ${ }^{44}$ and a communications subsidiary of ITT filed a competing application for authority to provide similar facilities over a

\footnotetext{
${ }^{43}$ During 1960 both Western Union and the Commercial Cable Company suffered substantial losses in revenues from leased channel services. The primary cause for the decline was the action of the Department of Defense in cancelling certain of its leases with Commercial Cable at the end of 2959 totaling some $\$ 420,000$ in annual rents; subsequently in April r960 additional leases were cancelled with Western Union totaling some $\$ 500,000$ in annual rents. The carriers attributed such cancellations in part to the closing of a U.S. government communications center in Europe and in part to the government's decision to lease voice-grade circuits in the TAT-I cable from AT\& $T$ for alternate or simultancous voice or telegraph use. Such new leases permitted the government to obtain telegraph channels at proportionately lower rentals than were available from the telegraph carriers.

"Application of American Tel. \& Tel. Co., File No. P-C-5494 (Oct. 4, 1963).
} 
somewhat different route. ${ }^{45}$ Upon consideration of all the pleadings, the Commission issued its so-called $T A T_{-4}$ decision. ${ }^{46}$ In that decision, the Commission determined that it would grant the application of AT\&T and deny the competing application subject to the condition that AT\&T share the ownership of the cable with the international telegraph carriers on the basis of a formula prescribed by the Commission and on the further condition that AT\&T provide no additional alternate and simultaneous voice/data services ${ }^{47}$ over any of the facilities which AT\&T operated for international telecommunication services.

The $T A T-4$ case and other decisions ${ }^{48}$ enabled the international telegraph carriers to provide themselves with modern cable facilities over all AT\&T cables at the same relative costs that were applicable to $A T \& T$. In foreclosing $A T \& T$ from the voice/ data market for leased services in the future, the Commission preserved this growing area to the various competing international telegraph carriers. This market was designed to give them a secure customer base and enable them, although competing among themselves, to derive adequate revenues so that they could continue to provide international message telegraph service at reasonable rates to the using public rather than suffer the fate of the domestic telegraph carrier, The Western Union Telegraph Company. Domestically, telegraph service had been continuously plagued, since the end of World War II, with increasing costs, increasing charges, and steadily decreasing volumes. Between 1945 and 1964 , the total volume of domestic telegrams had dropped from 236 million to ninety-seven million, a decrease of sixty per cent. At the same time, the basic charge for a public message telegram had increased $\mathrm{r} 6 \mathrm{I}$ per cent.

\section{III}

\section{Moving into the Sateldite Era}

As a result of the regulatory policies just described, several conditions existed in I964, at the dawn of the age of satellite communications: active competition among the several telegraph carriers; joint ownership of modern high-capacity international cable facilities; a tremendous rate of growth in the demand for international telephone facilities (for telephone messages alone, approximately twenty per cent growth per year compounded); and even more rapidly increasing demand for international telex service (over thirty per cent per year compounded); and a very rapid growth in leased circuits facilities.

As a result of development of rocket weaponry and electronic equipment during World War II and further experimentation during the early years of the Cold War,

\footnotetext{
${ }^{85}$ Application of Mackay Radio \& Tel. Co., File No. P-C-5562 (Jan. 6, I964).

10 American Tel. \& Tel. Co., 37 F.C.C. II5I (I964).

${ }^{47}$ Tariff FCC No. 43, I9th Revised Page 19, of ITT World Communications Inc., describes these services as cable or satellite facilities of voice quality, which may be used alternately or simultaneously for voice, data, or other record communication.

${ }^{4}$ Mackay Radio \& Tel. Co., FCC 64-4I (Jan. 22, x964).
} 
it became reasonably clear that man would soon be able to escape the grip of gravity and place objects into orbit around the earth. In fact, shortly after World War II, Arthur Clarke, a scientist and author, wrote an article ${ }^{40}$ suggesting the possibility that man would be able to place a satellite with electronic communication equipment into orbit at an altitude of about 22,300 miles above the equator. At that altitude, a satellite would revolve around the earth in twenty-four hours or exactly the same time that it takes the earth to rotate on its axis. Thus, the satellite would appear to hover above the earth at a fixed point over the equator. Such a satellite could send radio signals to cover about one third of the earth, and therefore three such satellites could provide global communications.

In the mid-I940s, this article was dismissed as another exercise in science fiction. However, about one decade thereafter, the Russians demonstrated, with Sputnik, that man could, in fact, break away from the pull of gravity. Shortly thereafter, the United States launched its own first satellite, and the space age was upon us. This development in rocketry, together with the rapid advances made in the electronics field, indicated clearly that one of the earliest uses that could be made of this scientific breakthrough would be in the provision of communication facilities via satellite.

While the National Aeronautics and Space Administration (NASA) continued its series of experiments with various types of launch vehicles and electronic and communication satellites, the U.S. government formed an interagency committee to give consideration to the exploitation of the technology in the communications field. The Commission organized an ad hoc committee of interested carriers to study the problems involved in the provision of communication service via satellite and make recommendations to it..$^{50}$ After receiving this committee's report, the Commission recommended to the Congress, particularly on the basis of such report, that satellite communications facilities should be developed within the context of our traditional philosophy under which telecommunications facilities of the nation are owned and operated by regulated private enterprise. ${ }^{51}$

The Commission's recommendation was strenuously opposed by those who felt that space developments, financed largely by government funds, should not be turned over to private industry but that, instead, satellite communications should be provided by a governmental entity. After lengthy and spirited debate in the Congress, a compromise was evolved and embodied in the Communications Satellite Act of $\mathrm{Ig62.52}$

${ }^{90}$ A. Clarke, The Exploration of Space i56 (x95I).

${ }^{50}$ Supplemental Notice of Inquiry, No. I4024 (F.C.C., July 25, I96r); Report of the Ad Hoc Carrier Committee, No. 14024 (F.C.C., Oct. I2, I96r).

${ }^{51}$ Hearings on Communications Satellites Before the House Comm. on Interstate and Foreign Commerce, 87th Cong., 2d Sess., pt. 2, at 401 (1962).

${ }^{52}$ Communications Satellite Act, 47 U.S.C. $\$ 701$ et seq. (1964). 
In essence, this act provided for a private corporation, Communications Satellite Corporation (Comsat), which was not to be an agency or establishment of the U.S. government. Comsat was to be the chosen instrument of the United States for the provision of satellite communications facilities in the international field. Under the act, the Commission was given the functions set forth hereinabove. The President was also given major responsibilities in such areas as (a) assisting in the planning, development, and execution of a national program for the establishment and operation of a commercial satellite communications system; ${ }^{53}(b)$ reviewing all phases of the development of the system $;^{54}(c)$ coordinating activities of governmental agencies with responsibilities in the field of communications; ${ }^{55}(d)$ supervising the relationships of Comsat with foreign entities to assure that they were consistent with the national interest and foreign policy of the United States; ${ }^{56}(e)$ insuring that timely arrangements would be made for foreign participation in the establishment and use of the system, ${ }^{57}$ and $(f)$ assuring the availability and utilization of the system for general governmental purposes..$^{58}$

NASA was also given a series of advisory functions, involving advice and assistance both to the Commission and to Comsat, including research and development. ${ }^{59} \mathrm{It}$ was also authorized to assist the Corporation by providing, among other services, launching facilities for research satellites and for operational satellites, approved by the Commission, on a reimbursable basis. ${ }^{60}$

Comsat began its corporate existence in early $\mathrm{x} 963$. By March of $\mathrm{x} 964$, it concluded a contract with Hughes Aircraft Company for the construction of a communications satellite to be placed into synchronous orbit. By mid-Ig64, it successfully floated a $\$ 200$ million stock issue. In August 1964 , agreements were concluded with major telecommunications entities in the world setting up interim arrangements for the operation of an International Satellite Consortium to provide international communications services via satellite. ${ }^{61}$

Thus, by 1964 , the existing U.S. terrestrial carriers had already constructed or had been authorized to construct a network of modern and relatively high-capacity cables connecting the U.S. mainland wtih Europe, the Caribbean area, South America, Hawaii, Japan, and the Philippines. On the other hand, Comsat was by now organized, an international consortium to exploit the satellite technology had been created, and a satellite was being constructed. It was now necessary, therefore,

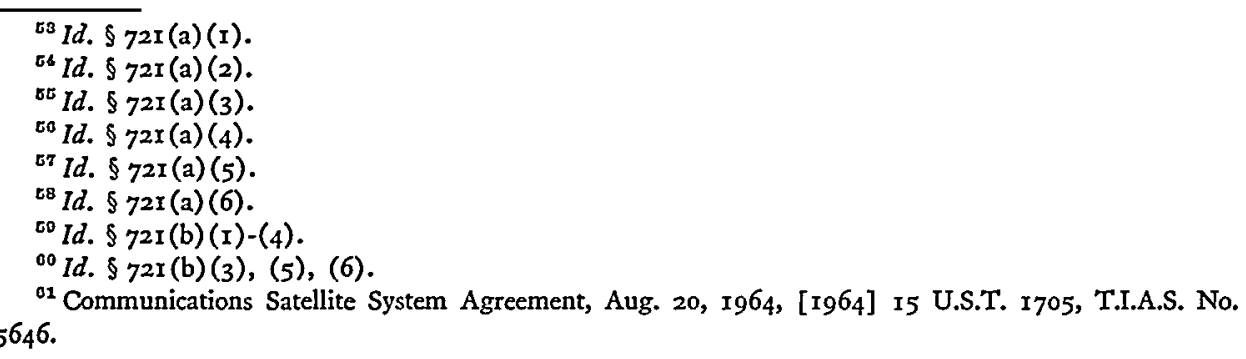


for the Commission to determine in the interim period, between the time the first satellite was ordered and the time it would be available for service, who should be authorized to construct and own earth stations, what services Comsat would provide, and how to insure that Comsat, which was not in a position to, and did not intend to, provide message telephone, message telegraph, or telex services directly to the public, would have an opportunity to provide an equitable share of the facilities required by the terrestrial carriers for these services. The Commission, in a series of proceedings, undertook to resolve each of these issues.

\section{IV}

\section{Earth Station OWNERship}

The earth station ownership issue was the first which became acute. Under the Satellite Act, the Commission was authorized to license Comsat, or one or more carriers, or Comsat and one or more carriers, to operate the earth stations. ${ }^{02}$ To resolve this matter, the Commission requested advice on what rules or policies it should adopt regarding the ownership of earth stations. ${ }^{63}$ After receiving the views and recommendations form the interested parties, the Commission issued its first Report and Order in this matter. ${ }^{84}$ In this report, the Commission noted that it was generally agreed that for the next several years such stations would be needed in three areas, namely in the northeastern and northwestern sections of the U.S. mainland and in Hawaii. On this basis, the Commission determined that these three earth stations should initially be owned and operated by Comsat and that the point of interface between Comsat and the terrestrial carriers should be at the gateway city nearest to the respective earth stations. The terrestrial carriers filed petitions for reconsideration of this report on both counts. Upon reconsideration, the Commission reaffirmed its ownership decision but held that the interface should be moved back to the earth station sites. This, in essence, permitted terrestrial carriers to provide the facilities between the gateway cities and the earth stations. ${ }^{65}$

As noted at the time the Commission issued its initial report on earth station ownership, it was not visualized that additional earth stations would be required in the United States for sometime in the future. However, it quickly became apparent that satellite communications were moving at a much faster pace than originally anticipated; that a second generation of satellites, Intelsat II, were being planned for early development and that service via these satellites would require additional antennas. It was felt that these antennas should be located further south than the original antennas. Thus, within ten months of the first report, an application was filed

\footnotetext{
${ }^{62} 47$ U.S.C. $\$ 721$ (c) (7) (I964).

${ }^{68}$ Notice of Proposed Rule Making or Formulation of General Policy, No. 15735 (F.C.C., Dec. 9, I964).

oi Proposed Global Commercial Communication Satellite System, 38 F.C.C. Iro4 (1965).

${ }^{65}$ Ownership and Operation of Earth Stations, 5 F.C.C.2d 8r2 (1966).
} 
by Comsat for an additional earth station in West Virginia. ${ }^{68}$ Some seven months thereafter, Comsat filed to build an earth station in southern California. ${ }^{67}$ The terrestrial carriers filed a competing application with respect to Comsat's West Virginia application, specifying a location in Georgia or, alternatively, in West Virginia. ${ }^{68}$ In addition, a communications subsidiary of the International Telephone and Telegraph Corporaton (ITT Cable and Radio Inc.-Puerto Rico) filed an application for an earth station in Puerto Rico. ${ }^{69}$ Comsat, in turn, filed a competing application for an earth station in the neighboring Virgin Islands, later superseded by an application specifying a Puerto Rico site. ${ }^{70}$ To complicate matters further, AT\&T filed an application for a second cable between Florida and the Virgin Islands, having a capacity of 720 voice circuits, ${ }^{71}$ and a communications subsidiary of International Telephone and Telegraph Corporation filed an application to participate in the ownership and operation thereof. ${ }^{72}$

The Commission was now involved with a whole complex of competing applications, all beyond the scope of its original earth station ownership report, which had addressed itself only to the ownership of the three earth stations in the northeastern and northwestern parts of the continental United States and in Hawaii, and had left the ownership of other earth stations for future decision. In order to resolve this matter as expeditiously as possible, and to obviate the need for the conduct of time-consuming and potentially acrimonious hearings on the whole series of competing applications, the Commission entered into discussions with all of the interested parties to consider ways and means of resolving the potential impasse.

After considering the formal pleadings of the parties and the results of the discussions of the carriers, the Commission issued a further report on the question of ground station ownership. ${ }^{73}$ In essence, the Commission indicated that it would alter its original interim policy and instead adopted a new one applicable to all six stations, the three existing and the three proposed. The Commission stated that it would entertain new joint applications, pursuant to which the three existing earth stations in the northeastern and northwestern United States and in Hawaii, as well as the three proposed earth stations in the southeastern and southwestern continental United States and in Puerto Rico, would be owned jointly by Comsat and the terrestrial carriers. In each instance, Comsat would own fifty per cent of the earth stations and would act as station manager. The other fifty per cent would be divided

\footnotetext{
${ }^{00}$ Application of Comsat, File No. Io-CSG-P-66 (March 30, 1966).

or Application of Comsat, File No. 26-CSG-P-67 (Oct. 26, 1966).

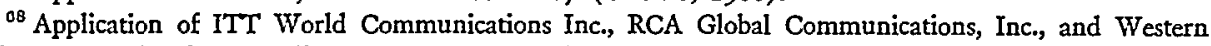
Union International, Inc., File No. I5-CSG-P-66 (May Ix, I966).

${ }^{\circ 0}$ Application of ITT Cable \& Radio, Inc.-Puerto Rico (now All America Cable \& Radio, Inc.), File No. 8-CSG-P-66 (Nov. 22, I965).

${ }^{70}$ Application of Comsat, File No. I4-CSG-P-66 (Apr. 25, I966); superseded by Application, File No. 28-CSG-P-67 (Nov. 16, I966).

${ }^{71}$ Application of American Tel. \& Tel. Co., File No. P-C-6290 (Feb. I7, Ig66).

${ }^{79}$ Application of ITT Communications, Inc.-Virgin Islands, File No. P-C-6290 (Feb. 25, I966).

${ }^{73}$ Ownership and Operation of Earth Stations, 5 F.C.C.2d 812 (I966).
} 
among the international telephone and telegraph carriers providing service. Thus, in the continental United States, the fifty per cent terrestrial carrier shares would be owned as follows: AT\&T, 28.5 per cent; ITT World Communications Inc., 7.0 per cent; RCA Global Communications, Inc., I0.5 per cent; and Western Union International, Inc., 4.0 per cent. In Hawaii, Hawaiian Telephone Company would own 30 per cent; ITT World Communications Inc., 6.o per cent; RCA Global Communications, Inc, Ix.o per cent; and Western Union International, Inc., 3.0 per cent. In Puerto Rico: IT'T Cable and Radio, Inc.-Puerto Rico (now All America Cables and Radio, Inc.), 30 per cent; ITT World Communications Inc., II.5 per cent; RCA Global Communications, Inc., 4.0 per cent; and Western Union International, Inc., 4.5 per cent. ${ }^{74}$

The above-described policy for the joint ownership of the six earth stations is to remain in effect until the end of 1969 . In October 1969 , the interested parties are to submit a report to the Commission regarding operations under the policy, together with appropriate recommendations as to what, in their opinion, would be the proper policy to be followed thereafter with respect to the ownership of earth stations. ${ }^{75}$

\section{V}

\section{Competing Cable Applications}

\section{A. The Caribbean Area}

The Commission at the same time it issued its policy statement on earth station ownership also addressed itself to the competing applications for an earth station in Puerto Rico and a cable between the United States and the Virgin Islands.

In considering whether either or both of these applications should be granted, the Commission noted the following: ${ }^{76}$

(a) that there was an urgent need for additional facilities between the U.S. mainland, on the one hand, and Puerto Rico and the eastern Caribbean area, on the other hand, to meet the needs of the public for communication services;

(b) that this area accounted for a substantial share of total overseas traffic (for example, telephone calls between the United States and the area accounted for more than twenty per cent of all overseas calls from the U.S. mainland in I965);

(c) that traffic between the United States and this area was growing more rapidly than to most other portions of the world, with traffic between the mainland and Puerto Rico-Virgin Islands having an average annual growth rate of thirty-three per cent for the years $1960-1965$ as against an annual

\footnotetext{
${ }^{31}$ Id. at $8 \mathrm{Ig}$.

${ }^{75} 1 d$. at 822 .

${ }^{70}$ International Tel. \& Tel. Cable \& Radio, Inc.-Puerto Rico, 5 F.C.C.2d 823 (1966).
} 
average growth rate of $x 7.6$ per cent for traffic between the mainland and other parts of the world in the same period;

(d) that a grant of the application would result in very substantial rate reductions, ranging between twenty-five and forty-five per cent, in the charges for message telephone service and leased circuit service and that such reductions could be expected further to stimulate demand;

(e) that a grant of the earth station application would provide the first such facility in the Caribbean area and demonstrate the U.S. commitment to the expansion of satellite facilities;

(f) that the cable application was the first for a transistorized high-capacity (720 circuits) cable and that orderly and continued progress in cable technology was in the public interest;

(g) that, with the installation of very high-capacity cables and satellites, there was a need for redundancy in facilities to assure continuity of service in case of cable interruption or satellite failure.

On the basis of all of the foregoing considerations the Commission determined that the public interest would be served by the grant of both the application for an earth station and the application for authorization to land and operate the proposed cable. In its Memorandum Opinion the Commission noted that AT\&T and ITT undertook to lease a hundred voice circuits for satellite use between Puerto Rico and the mainland as soon as the earth station facilities became available. Furthermore, the Commission recognized that there was merit to Comsat's fears that, under the authorized user decision discussed below, the cable owners might first satisfy all service requirements by using cable facilities and leave the earth station relatively idle. There was particular concern in this regard because the cable might be put into service first and therefore have the advantage of pent-up demand for facilities. To reassure Comsat that the dangers it foresaw would not come to pass, the Commission required that the cable and satellite be used equitably. First, this meant that none of the carrier owners of the cable could, after the earth station became operable, use any circuits in the cable to serve the Puerto Rico-Virgin Islands area, as well as points beyond served via Puerto Rico, until such carrier had leased satellite circuits equal in number to the total such carrier was then using in the cable. Thereafter, additional circuits requirements to the entire area were to be satisfied on a fifty-fifty basis, in accordance with a schedule of use agreed upon between the owners of the cable and the owners of the earth station or, in the event of disagreement, as prescribed by the Commission.

Both the cable and satellite facilities have been completed pursuant to the authorizations of the Commission. It is interesting to note that when the Intelsat III satellite, serving the Atlantic Ocean area, failed in June 1969 and a severe shortage of facilities to the entire area existed, it was possible to partially alleviate this shortage by placing mainland-eastern Caribbean traffic then being handled by satellite, on the 
new transistorized cable, thus freeing the satellite capacity, which otherwise would have been required for use on that route, for assignment to the numerous other earth stations in the Atlantic Basin for providing service on other routes.

\section{B. Another Transatlantic Cable (TAT-5)}

In the fall of 1967 AT\& $T$ informally advised the Commission and other interested government agencies that it had been conducting discussions with Spanish, Portugese and Italian communication interests regarding the possibility of laying a fifth transatlantic cable (TAT-5) between the United States and a landing point in either Portugal or Spain. AT\&T pointed out that the four previous transatlantic cables had terminated either in England or in France and provided service directly to northern Europe. The countries in southern Europe, according to AT\&T, were also interested in having direct cable communications between the United States and their respective countries. AT\&T further stated that the Italian communication interests were planning to lay a cable across the Mediterranean from Italy to Spain which, in addition to meeting purely intra-European needs, would also provide direct access from the United States to Italy through interconnection with the proposed TA'T-5 via either Spain or Portugal.

Questions immediately arose regarding the need for such a cable and, if needed, its relationship to existing and planned satellite facilities. At that time, Comsat and the International Telecommunications Consortium (Intelsat), of which Comsat was a member, had under contract a new generation of satellites, Intelsat III, which were scheduled to be in service during the first half of ig68. Furthermore, Comsat advised that Intelsat was planning a fourth generation of satellites (Intelsat IV) to be in service in the early I970s.

It became clear early in the course of the discussion that Comsat was opposed to the authorization of the proposed $\mathrm{TAT}_{5}$ on the grounds that it would unnecessarily duplicate the aforementioned satellite facilities which were needed to provide service to the entire Atlantic Basin and would be placed in service whether or not TAT-5 was authorized. It was further argued by Comsat that if $\mathrm{TAT}_{-5}$ were authorized, it would deprive the satellite facilities of traffic they would otherwise have handled thereby making the cost per satellite circuit higher to all users of that facility. The Commission then prepared a series of lengthy interrogatories to both Comsat and the terrestrial carriers raising questions with respect to foreseeable volumes of traffic, relative costs of each of the proposed facilities, when it was expected the facilities would be filled, and the proposed charges to the public. A vast amount of data, accompanied by arguments from each of the two opposing sides, was filed with the Commission. These data were analyzed not only by the Commission but also by the Department of State, which shares with the Commission the responsibility for granting cable landing licenses, and by the Director of Telecommunications Management to whom responsibilities with respect to satellite communications has 
been assigned. ${ }^{77}$ In addition, the Task Force on Communications Policy established by President Johnson in August $1967^{78}$ to study various aspects of international communications and certain other matters also participated in the review and analysis.

After completing its review, the Commission, with the concurrence of the Department of State, concluded that it would entertain an application for TAT-5 subject to the following conditions: ${ }^{79}$

(a) that the cable be completed no later than March 3 , 1970 , to meet an expected shortage of facilities after existing and planned satellite facilities had been installed and were fully saturated and before the next generation of satellites could be constructed and placed in orbit;

(b) that AT\&T and the telegraph carriers who would jointly own the American end of the cable would secure agreement from their foreign correspondents that the cable (TAT-5) and the satellite facilities (Intelsat III and Intelsat IV) serving the Atlantic Ocean region would be used in such fashion that both facilities would be filled at approximately the same time; and

(c) AT\&T and the telegraph carriers will include in the application for the cable agreements with their proposed foreign correspondents an undertaking to reduce present telephone rates by at least twenty-five per cent and to reduce present leased channel service rates by more than twenty-five per cent by the date the cable is open for service. ${ }^{80}$

In its letter to Comsat with regard to $\mathrm{TAT}_{-5}$, the Commission also indicated that it expected Comsat to proceed as expeditiously as possible with the planning for and launching of the next generation of high-capacity satellites (Intelsat IV).

The terrestrial carriers accepted the terms and conditions and filed an application for authority to construct and operate $\mathrm{TAT}_{5}$ in accordance therewith. They also attached to such applications copies of agreements with their foreign correspondents with respect to both proportionate fill and reductions in charges. On May 22, 1968, the Commission authorized the TAT-5 cable. ${ }^{81}$ This cable is now under construction and is scheduled for service by the end of March 1970 .

In October 1968 Intelsat authorized the construction of a fourth generation of satellites, Intelsat IV, in only four years of satellite existence. These satellites are scheduled to be operational beginning in the first quarter of 1971 .

\footnotetext{
${ }^{77}$ Executive Order III9I, $30 \mathrm{Fed}$. Reg. 29 (1965).

${ }^{78}$ H.R. Doc. No. 157, goth Cong., Ist Sess. 8 (I967).

${ }^{70}$ Letters from the FCC to AT\&T, Comsat, ITT World Communications Inc., RCA Global Communications, Inc., and Western Union International, Inc., February x6, 1968, II F.C.C.2d 957 (I968).

${ }^{80}$ The telegraph carriers were requested to include in the application definite proposals for reducing rates for message telegraph and telex services. In the TAT-5 authorization, the Commission prescribed a reduction for message telegraph rates as of the date the cable becomes operational.

${ }^{81}$ American Tel. \& Tel. Co., I3 F.C.C.2d 235 (I968).
} 


\section{The Authorized User INQuiry}

The Satellite Act authorizes Comsat among other things to furnish for hire channels of communication to U.S. communications common carriers and to other authorized entities, foreign and domestic, ${ }^{82}$ and, in this connection, to contract with authorized users, including the U.S. government, for the services of the communications satellite system. ${ }^{83}$ The Satellite Act, however, did not define "other authorized entities," and questions therefore arose whether Comsat could provide service directly to ultimate users or whether it is to provide its facilities only to existing communications common carriers, which in turn would make use of them to provide service to the general public. In order to resolve these questions, the Commission instituted the so-called Authorized User Inquiry, ${ }^{84}$ wherein it raised the aforementioned questions and requested interested parties to make appropriate filings supported by briefs and the legislative histories of the act.

After reviewing the conflicting views of the various parties, the Commission determined $:^{85}$

(a) that Comsat was, by law, authorized to provide communication service to entities other than communications common carriers;

(b) that as a matter of policy, and except in unusual circumstances, the Commission would not authorize Comsat to provide service directly to the ultimate user;

(c) that Comsat could conduct research to demonstrate the availability and usefulness of satellite communications and could actively solicit customers for satellite facilities;

(d) that in any instance where satellite facilities were requested by a user and were available and where terrestrial carriers failed or refused to provide such satellite service, Comsat would be authorized to provide the satellite service directly to such customer (this should operate to protect Comsat from possible action by terrestrial carriers favoring their own terrestrial facilities);

(e) that, insofar as service to the U.S. government was concerned, the Commission would look to the Director of Telecommunications Management for advice as to whether the national interest would be served by permitting Comsat to provide service directly to agencies of the U.S. government and would take appropriate action after considering such advice; and

(f) that the terrestrial carriers were expected to reflect, in their charges to the

${ }^{82} 47$ U.S.C. $\$ 735$ (a) (2) $(1964)$.

${ }^{83}$ Id. $\$ 735$ (b) (4).

${ }^{84}$ Notice of Inquiry, No. 16058 (F.C.C., June 16, 1965).

${ }^{88}$ Authorized Entities and Users-Comsat, 4 F.C.C.2d 421 (Ig66). See also Public Notice adopted June 23 , I966, 4 F.C.C.2d I2 (I966). 
public, the economies made available to them through the lease of satellite circuits from Comsat.

In reaching this decision the Commission took note of the fact that, by law, Comsat had a monopoly in the provision of satellite facilities for international communications services. Therefore, the carriers were required to lease these facilities from Comsat and could not provide them for themselves. Secondly, Comsat did not intend to and could not provide the entire spectrum of international communications services-that is, message telephone service, message telegraph service, and telex service-directly to the using public. The only service it was seeking to provide or intended to provide was the leased circuit service. This was one of the fastest growing services and the loss of this service could seriously adversely affect the terrestrial carriers, particularly those providing telegraph service. If Comsat, which had a monopoly in the provision of satellite facilities, were to provide leased circuit services to the public at the same charge at which it made these facilities available to the carriers, the carriers would necessarily lose their customers, while Comsat would still realize the same revenues and would suffer no losses because of the decision. Furthermore, the carriers had, through the years, built and installed the then most modern facilities, and these were still operable and had not been fully depreciated. They could not compete with Comsat's newest facilities if they were to be deprived of the opportunity to average their costs and fix rates on the basis of composite costs. Under these circumstances, the vast majority of the using public which relies upon message telephone, message telegraphy, and telex would necessarily be required to pay much higher charges than now obtained for these services. Accordingly, the Commission determined to limit Comsat to the role of the carrier's carrier, with the exceptions noted above, and at the same time required the carriers to reflect the economies made available to them in the charges for the services they provided.

\section{VII}

\section{RATES}

A primary concern of users of telecommunications services is that the rates for such services should be just and reasonable. The Communications Act, in fact, imposes such an obligation with respect to the charges of all communication common carriers. ${ }^{86}$ The Satellite Act goes even further and requires the Commission to "insure that any economies made possible by a communications satellite system are appropriately reflected in rates for public communication services." 87 A considerable portion of the Commission's regulatory activities in the common carrier field is, therefore, necessarily addressed to the reasonableness of the charges made for communications services.

\footnotetext{
${ }^{80} 47$ U.S.C. $\$ 20 x(b)(1964)$.

${ }^{87} 47$ U.S.C. $\$ 72 \mathrm{I}(\mathrm{c})(5)(1964)$.
} 
In the period after World War II, the carriers, in an attempt to stimulate trafic, substantially decreased their charges for message telegraph service. Unfortunately, a combination of decreased traffic volume and increasing costs substantially reduced the earnings of the telegraph carriers. In order to cope with this situation, the Commission initiated a proceeding to determine the revenue requirements of the carriers, the basis upon which rates should be determined, and the adjustments, if any, which should be made in then existing rate levels. ${ }^{88}$ As a result of this proceeding, a series of interim rate increases were authorized between 1947 and $1950^{80}$

In 1949 an international conference was held under the aegis of the International Telecommunications Union to consider revision of the international telegraph regulations. At this conference, substantial adjustments were made in the categories of international message telegraph services which were to be provided and in the ratio of charges between such categories of service. As a result of the treaty which was proposed by this conference and which was ratified by the President with the advice and consent of the Senate, ${ }^{90}(a)$ full-rate messages in plain language and code, for which there had previously been a $33^{1 / 3}$ per cent reduction from the full-rate charges, were unified at seventy-five per cent of the former per-word charge for full-rate traffic; $(b)$ the category of deferred traffic, a reduced-rate service, was abolished; and (c) the per-word rates for letter traffic (messages normally delivered the day after they are filed) were fixed at fifty per cent of the new full rate in lieu of the previous charge of $33^{1 / 3}$ per cent of the old full rate. These various adjustments, together with the recovery in the volume of traffic, the expansion of direct service to numerous places in the world, and the gradual introduction of new services, such as telex, enabled the carriers to restore their relatively favorable earnings position.

No further consideration was given to rate adjustments until $195^{6}$ when The Western Union Telegraph Company requested an increase in its share of the charges for the domestic handling of international telegraph message traffic. The international carriers claimed that they could not absorb this increase in charges without adjustment in rates to the public. The Commission then instituted a general investigation ${ }^{91}$ into the rates and charges for international traffic to determine what adjustments, if any, should be made. Before resolving the issue with respect to rate adjustments, however, the Commission found it necessary to determine the policy it should follow in fixing rates in an industry where there were several competing carriers. In general, one of two different courses was available to the Commission. It could determine revenue requirements in such a way as to allow a fair return on an industry-wide rate base of all carriers providing service or on the rate base of that

\footnotetext{
${ }^{85}$ Order adopted March I2, I947, No. 8230 (F.C.C.).

${ }^{80}$ Charges for Communications Service Between the U.S. and Overseas and Foreign Points, 12 F.C.C. 29 (1947); I2 F.C.C. 926 (1948); 13 F.C.C. 459 (I949); I4 F.C.C. 523 (1950).

80 Telecommunications Agreement. Aug. 5, I949, [I95I] 2 U.S.T. I7, T.I.A.S. No. 2175.

${ }^{81}$ Order of March 13, 1957, No. xx953 (F.C.C.). See also Western Union Tel. Co., 25 F.C.C. 535 (I958).
} 
segment of the industry which was most profitable and also sufficiently large to meet the service requirements of the public (the so-called bellwether approach). The Commission chose the latter course and fixed the rates on the basis of the revenue requirements of RCA Global Communications, Inc., which it had found to be the most profitable carrier providing general world-wide service. ${ }^{22}$

Since $195^{8}$ there have been no formal rate hearings in the international field. There have, however, been a series of rate adjustments in the various categories of services provided by the international carriers. Thus, in I 966 there were minor rate increases for message telegraph traffic to compensate the international carriers, in part, for the rate adjustments required by Western Union for its domestic pick-up and delivery services, that is the domestic handling of international traffic. ${ }^{93}$ On the other hand, there has been the equivalent of a rate reduction in telex traffic to many points in Europe, where the minimum charge was reduced from a $\$ 9$ minimum for a three-minute period to a $\$ 3$ minimum for a one-minute period. Thus, it is now possible to make a telex call to many places for a charge of $\$ 3$ if the call does not last longer than one minute instead of paying the previous $\$ 9$ minimum charge which was applicable no matter how long the call lasted.

The largest reductions, however, have taken place in leased circuit charges. While there were some adjustments during the decade of the $1950{ }^{94}{ }^{94}$ the major reductions took place after the issuance of the Commission's Authorized User decision, which, as noted above, specifically required the carriers to reduce rates to reflect the economies made possible by satellite services. Table $\mathrm{I}$ indicates that rate reductions ranging between thirty and forty per cent have been put into effect to representative countries during the past three years.

TABLE I

Monthly Rates for U.S. Carriers' Terminal for Overseas Leased Circuit Services

\begin{tabular}{|c|c|c|c|c|}
\hline & \multicolumn{2}{|c|}{1965} & \multicolumn{2}{|c|}{1969} \\
\hline & Voice & $\begin{array}{l}50 \text { baud } \\
\text { Printer }\end{array}$ & Voice & $\begin{array}{l}50 \text { baud } \\
\text { Printer }\end{array}$ \\
\hline 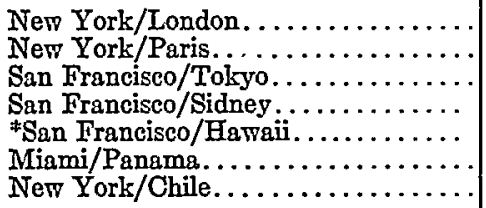 & $\begin{array}{l}\$ 8,500 \\
10,000 \\
15,000 \\
15,000 \\
17,000 \\
7,000 \\
\neq \neq\end{array}$ & $\begin{array}{r}3,500 \\
3,500 \\
4,000 \\
4,000 \\
6,160 \\
4,000 \\
4,000\end{array}$ & $\begin{array}{r}\$ 6,000 \\
6,600 \\
10,000 \\
10,000 \\
8,400 \\
3,875 \\
6,000\end{array}$ & $\begin{array}{r}\$ 2,400 \\
2,400 \\
3,500 \\
4,000 \\
2,750 \\
1,550 \\
2,400\end{array}$ \\
\hline
\end{tabular}

FRata is for both terminals.

$\Rightarrow$ No service.

${ }^{02}$ Western Union Tel. Co., 25 F.C.C. 535 (x958).

${ }^{03}$ Western Union Tel. Co., 3 F.C.C.2d $3 \times 4$ (1966).

${ }^{0}$ Leased voice channel rates between the U.S. mainland and the United Kingdom were reduced from $\$ 25,000$ for both terminals in 1958 to $\$ 77,000$ for the overseas channel plus landline haul; and between the U.S. mainland and France such rates have been reduced from $\$ 25,000$ for both terminals in r957 to $\$ 20,000$ for the overseas channel plus landline haul in 1959 . 
No formal proceedings have been held with respect to message telephone rates in the international field. However, with the introduction of service via the transoceanic repeaterized telephone cables, there have been substantial adjustments in rates. Prior to the laying of these cables, the standard service offered was a personto-person call with a charge of $\$ 12$ for three minutes. After the cables were installed, a station-to-station service with a $\$ 9$ charge was offered, and in many areas a reduced night-time rate was also offered. The per-minute charge for use beyond the initial period for person-to-person calls was reduced to the level of the station-to-station per-minute charge. In the case of Hawaii, the installation of cable facilities was followed by substantial rate adjustments. Thus, in 1969 the charge for a station-tostation call between Hawaii and California is $\$ 5.25$ for three minutes against a charge of $\$ 7.50$ for a person-to-person call in 1957 , the only class of telephone calls available prior to the opening of the cable. When the very high-capacity transistorized cable to the Virgin Islands was authorized, the telephone company undertook and actually implemented an average of twenty-five per cent rate reduction over-all when the cable was put into service. ${ }^{95}$ Similarly, in connection with the authorization of TAT-5, the telephone company undertook to apply an average twenty-five per cent rate reduction when that cable is available for service. This rate reduction is scheduled to be implemented early in 1970.96

Technological developments will make it possible in the relatively near future for users to dial directly their calls to an ever-increasing number of foreign points. Such direct dialing will decrease costs and make it possible to implement further rate reductions. In fact, this service is expected to be introduced with the United Kingdom

${ }^{95}$ Tariff amendments were filed effective September 23, I968 (AT\&T Tariff, FCC No. 263), which, in addition to reducing rates for telephone calls between the mainland and Puerto Rico and U.S. Virgin Islands by $25 \%$, introduced a new low rate for customer-dialed telephone service. A comparison of the level of station-to-station rates before and after the opening of the cable is given below:

\begin{tabular}{|c|c|c|c|c|}
\hline \multirow[b]{2}{*}{ Station-to-Station calls } & \multicolumn{2}{|c|}{ Day } & \multicolumn{2}{|c|}{ Night } \\
\hline & Prosent rate & Pravious rate & Present rate & Provious ratg \\
\hline 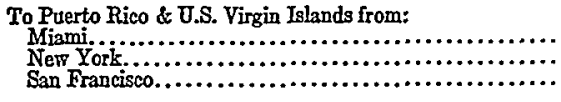 & $\begin{array}{r}\$ 4.80 \\
5.40 \\
6.00\end{array}$ & $\begin{array}{r}\$ 5.50 \\
6.50 \\
7.50\end{array}$ & $\begin{array}{r}\$ 2.70 \\
3.00 \\
3.30\end{array}$ & $\begin{array}{r}\$ 4.50 \\
5.50 \\
6.50\end{array}$ \\
\hline 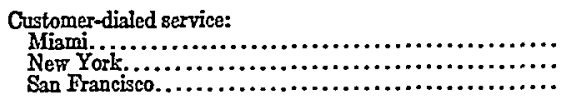 & $\begin{array}{l}4.05 \\
4.65 \\
5.10\end{array}$ & $=$ & $\begin{array}{l}2.25 \\
2.65 \\
2.85\end{array}$ & $=$ \\
\hline
\end{tabular}

Rates are for initial three-minute period. Additional minutes are priced at $1 / 3$ of the initial rate rounded to nearest five cents. The rates for the initial period for person-to-person calls were retained, except that the rate from Miami was reduced from $\$ 8.00$ to $\$ 7.50$ for the first three minutes. The charges for additional minutes for all person-to-person calls were reduced to the new level of station-to-station calls.

${ }^{\circ B} \mathrm{~A}$ new schedule of classes and applicable charges for telephone calls with European countries and the United Kingdom is currently under negotiations between AT\&T and its foreign correspondents. Reductions will be made in rates for all classes of calls and in some instances a new class, "customerdialed," will be introduced as the lowest rate class. The over-all reduction should average over $25 \%$ from present rates. 
by the end of this year or early next year. At that time the basic charge for stationto-station calls is expected to be reduced from the present level of $\$ 7.4^{\circ}$ for a station-to-station call placed through an operator to $\$ 3.60$ for a three-minute direct dialed call.

The Commission, in reviewing the earnings of the international carriers in 1969 , found that they had been increasing steadily to levels substantially above those found reasonable in the $195^{8}$ rate case. ${ }^{97}$ It therefore has required the carriers to submit detailed data regarding current and expected revenues and expenses and has scheduled a conference for the latter part of September 1969, to discuss possible further rate reductions for all types of service provided by the telegraph carriers. In addition, informal discussions are expected to be held with the telephone company, looking toward a detailed review of current message telephone charges for service to all parts of the world with a view to appropriate rate adjustments to rationalize such charges and to enable them to reflect the economies available as satellite and high-capacity cable service spreads to an increasing number of countries. It should be noted that all of these downward rate adjustments are taking place in a time of general inflationary pressures when most other costs are trending sharply upward.

\section{VIII}

\section{Merger of International Carriers}

As has been set forth in some detail, international telegraph service is provided by a group of competing carriers. Since communications service is a common carrier service in the nature of a public utility, there have been a continuous series of studies to determine whether, in fact, legislation should be passed to authorize or require the merger of the competing international telegraph carriers into a single entity. As early as 1929 hearings were held in Congress ${ }^{98}$ on this subject, but no action was taken. Consideration was again given to this matter during the r930s when the Communications Act of 1934 was under consideration. ${ }^{92}$ Thereafter, the Commission in early 1935 submitted a recommendation to Congress that a bill authorizing merger of competing international carriers be authorized..$^{100}$ No action was taken on this bill. Hearings were held in 1939 pursuant to Senate Resolution $95,{ }^{101}$ and recommendations in favor of merger were again made. ${ }^{102}$ During 1942 and 1943 , when the bill which authorized the merger of domestic facilities of Western Union and the

\footnotetext{
${ }^{07}$ Western Union Tel. Co., 25 F.C.C. 535 (1958).

${ }^{\mathrm{B}}$ Hearings on S. 6 Before the Senate Comm. on Interstate Commerce, 7Ist Cong., Ist Sess. (1929).

${ }^{00}$ Hearings on S. 2910 Before the Senate Comm. on Interstate Commerce, 73d Cong., 2d Sess. (1934); Hearings on H.R. 8301 Before the Hotlse Comm. on Interstate and Foreign Commerce, $73 \mathrm{~d}$ Cong., 2d Sess. (1934); H.R. Rep. No. I850, 73d Cong., 2d Sess. (I934); H.R. Rep. No. I9I8, 73d Cong., $2 d$ Sess. (r934).

${ }^{100}$ H.R. Doc. No. 83, 74th Cong., Ist Sess. (1935).

${ }^{101}$ S. Res. 95, 76th Cong., Ist Sess. (1939), extended by S. Res. 268, 76th Cong., 2d Sess. (1940).

${ }^{102}$ S. REp. No. 769, 77th Cong., Ist Sess. 25 (194I).
} 
Postal Telegraph Company was under consideration, proposals were made for the authorization of the merger of international telegraph carriers, ${ }^{103}$ but no action was taken because the Department of the Navy felt that attempts to merge the carriers during the war might interfere with needed communications services. ${ }^{104}$

Passage of the international merger legislation was again considered in 1945-1947 but was not enacted because of the opposition of the Department of State. ${ }^{105}$ Thereafter, a Telecommunications Coordinating Committee was organized under the chairmanship of the Department of State in an attempt to establish a unified position of all government agencies on this subject. Unfortunately, the committee ended with both minority and majority reports, and again no action was taken. ${ }^{100}$ In 1950 President Truman appointed the President's Communications Policy Board to study, among other things, the subject of merging international carriers. This committee recommended against merger at that time..$^{107}$

On August 5, 1958, Senator Magnuson introduced a bill ${ }^{108}$ to permit the merger of international telegraph carriers. In $x 959$ the Senate Committee held hearings on a print of this bill. The Commission, in its testimony, approved permissive merger in principle and recommended enactment of a statute to that effect. ${ }^{100}$ This bill was opposed by the Department of Justice, and again no action was taken. ${ }^{110}$

In $x 964$ an interdepartmental committee co-chaired by the Chairman of the Federal Communications Commission and the Director of Telecommunications Management made a massive and detailed study of the problem. It determined that advances in technology had tended to eliminate the differences between telephony and telegraphy and concluded that a broader basis for merger might be considered. It was noted that a new element, Comsat, had been introduced into the international communications scene. Accordingly, the Committee unanimously recommended that a broadbased bill, authorizing the merger of two or more telegraph carriers with the international facilities of the telephone company as well as those of Comsat should be enacted. This report was submitted to the President in the fall of $1966,{ }^{111}$ but no action was taken on it. Instead, in April 1967, the President established a Task

\footnotetext{
${ }^{203}$ S. 2445, 77th Cong., 2 d Sess. (1942); see Hearings on S. 2445 Before a Stibcomm. of the Senate Comm. on Interstate Commerce, 77th Cong., 2d Sess. 1, 250 et seq. (1942).

${ }^{104} \mathrm{Id}$. at 122 .

${ }^{105}$ S. Res. 187, 78th Cong., Ist Sess. (1943), supplemented by S. Res. 268, 78th Cong., 2d Scss. (1944), extended by S. Res. 24, 79th Cong., rst Sess. (1945); S. Rep. No. 19, 8oth Cong., Ist Sess. (1947).

${ }_{108}^{13}$ FCC ANN. Rep. 68 (1947).

107 'Telecommonications, A Program for Progress, A Report by the President's Communications POLICY BOARD 15I-82 (I95I).

${ }^{108}$ S. 4231 , 85th Cong., 2d Sess. (1958).

${ }^{100}$ Hearings on $S .423 I$ Before the Senate Comm. on Interstate and Foreign Commerce, 86th Cong., Ist Sess. I0, 3 I (I959).

${ }^{110} \mathrm{Id}$. at $2 \mathrm{I}$.

111 Report and Recommendations to the Senate and House Committees of the INTra-Government Committee on International Telecommunications (Ig66).
} 
Force on Communications Policy ${ }^{112}$ to study among other things the question of whether legislation authorizing or requiring the merger of the various entities providing international telecommunications services should be enacted. The task force submitted its report in December rg68, specifically recommending the enactment of merger legislation. ${ }^{113}$ President Johnson did not act on the report or release it. Subsequently, on May 20, Ig69, it was released by President Nixon to a subcommittee of the Interstate and Foreign Commerce Committee of the House of Representatives without specific recommendation on this subject.

Thus, after forty years of study and periodic review, there has been no legislation enacted, and currently there is no official presidential recommendation for any legislation to authorize the merger of either the international telegraph carriers alone or the merger of such carriers with the international facilities of the telephone company or with Comsat.

\section{IX}

\section{Summary of Commission Pourcy}

The Commission's regulatory policy in the field of international communications may be summarized as follows:

(I) to permit, in the absence of merger legislation, the international telegraph carriers to compete between and among themselves by authorizing competing direct circuits whenever and wherever it finds that competition is reasonably feasible;

(2) to safeguard a share of the traffic to the competing international telegraph carriers so that they may have the opportunity to earn sufficient revenues to enable them to provide efficient, modern service without substantial upward adjustment in the charges for message telegraph service;

(3) to enable the competing international telegraph carriers to participate with the telephone company in the ownership of modern high-capacity terrestrial facilities so that their users may share in the economies of scale which these facilities provide;

(4) to give the terrestrial carriers a vested interest in making the greatest possible use of satellite facilities by allowing them to invest in and own a share of each of the earth stations used to provide international service;

(5) to restrict Comsat, in the international field, primarily to the role of a carrier's carrier so that the economies of satellite communications may be made available to all categories of the public, including those who are message telephone, message telegraph, and telex users as well as leased circuit users;

\footnotetext{
${ }^{112}$ H.R. Doc. No. 157 , 90th Cong., Ist Sess. 8 (I967).

${ }^{118}$ President's Task Force on Communications Policy, Final Report (1968).
} 
(6) to encourage the prompt installation of the most modern high-capacity facilities to meet rapidly growing customer requirements;

(7) to insure sufficient redundancy in high-capacity facilities so that the failure of any one facility will not unduly deprive the public of service for a lengthy period; and

(8) to insure that rates at all times remain reasonable and particularly that economies made possible by modern high-capacity satellite and cable facilities are promptly reflected in reduced rates to the using public. 